\title{
Spray-dried powder preparation of pumpkin sweet potato hydrolysates and its physicochemical properties
}

\author{
Dae-Hoon Lee ${ }^{1}$, Jong-Hyun Jang ${ }^{2}$, Joo-Heon Hong ${ }^{1 *}$ \\ ${ }^{1}$ Department of Food Science and Technology, Catholic University of Daegu, Gyeongsan 38430, Korea \\ ${ }^{2}$ Neulgreen Co., Goryeong 40112, Korea
}

\section{호박고구마 효소 분해물의 분무건조 분말 제조 및 물리화학적 품질특성}

\author{
이대훈 ${ }^{1} \cdot$ 장종현 $^{2} \cdot$ 홍주헌 $^{1 *}$ \\ ${ }^{1}$ 대구가톨릭대학교 식품공학전공, ${ }^{2}$ 농업회사법인 (주)늘그린
}

\begin{abstract}
This study was conducted prepare spray-dried powder using pumpkin sweet potato hydrolysates and examine the physicochemical properties of the powder. The insoluble dietary fiber and soluble dietary fiber of the pumpkin sweet potato treated by enzyme were $4.17 \%$ and $2.07 \%$, respectively. The spray-dried pumpkin sweet potato hydrolysates was manufactured via spray-drying with different forming agents: i.e., pectin $0.1 \%, 0.5 \%, 1 \%$, and 2.0\%. The moisture contents and total starches of the spray-dried powders were approximately 1.68-2.46 and $45.32-46.51 \%$, respectively. The color of the $L$ and a value decreased, and that of the $b$ and $\Delta E$ value increased. The particle size and outer topology of the spray-dried powders were 37.17-42.32 $\mathrm{m}$, and its shape was generally globular. The water absorption index of the spray-dried powder (1.74-1.91) was lower than that of the freeze-dried powder (2.15). The water solubility index of the spray-dried powder, $80.75-87.61 \%$, was higher than that of the freeze-dried powder $(\mathbf{7 0 . 4 7 \%})$. The adhesion values of spray-dried powder to epithelial HT-29 cells were $2.66-6.18 \%$ of the initial cell counts, whereas freeze-dried powder showed lower adhesive ability $(1.79 \%)$. The in vitro human digestibility in the spray-dried powder was $\mathbf{7 0 . 0 9 \%}$ which is very effective in digestion.
\end{abstract}

Key words : pumpkin sweet potato, hydrolysate, spray drying, physicochemical properties

\section{서 론}

최근 건강에 대한 관심이 증가하면서 친환경 농산물과 농약으로부터 영향이 적은 뿌리 및 땅속에서 얻는 식품에 대한 선호도가 증가하고 있다. 뿌리작물 중 고구마(Ipomoea batatas L.)는 전분질 식품으로 열량이 낮고 감자보다 식이 섬유 및 폴리페놀 함량이 높아 기능성을 갖는 건강증진 식품으로 알려져 있으며(1), 전세계적으로 중요한 식량작 물중 하나로 $95 \%$ 이상이 아시아와 아프리카 지역에서 생산

*Corresponding author. E-mail : jhhong@cu.ac.kr Phone : 82-53-850-3218; Fax : 82-53-850-3218

Received 8 March 2017; Revised 27 March 2017; Accepted 29 March 2017.

Copyright (c) The Korean Society of Food Preservation. All rights reserved.
되고 있다. 또한, 다른 작물에 비하여 척박한 땅에서도 잘 자라며 단위면적당 수확량이 많고 환경적응성이 강하므로 미래식량 또는 우주식량 자원으로 기대되고 있다 $(2,3)$. 이 러한 고구마를 육질색에 의해 구분할 경우 흰색인 일반고구 마와 자색 및 주황색을 나타내는 유색고구마로 나누어진 다. 고구마 육질이 오렌지색을 띠는 호박고구마는 보통고 구마에 비해 $\beta$-carotene 함량이 대단히 높아 다이어트 효과, 항산화, 항암작용, 심혈관계 질병 및 백내장 예방 등의 생리 활성 기능성이 우수한 것으로 알려져 있다(4). 그러나, 고구 마는 수분함량이 많고 추위에 약하며 저장 중 호흡열이나 탄산가스 발생량이 많아 저장 및 수송 등에 어려움이 있으 므로, 생산 후 짧은 시간 내 가공용 또는 생식용으로 소비되 어야 하는 문제점이 있다(5). 또한, 고구마는 주로 불용성 식이섬유소인 셀룰로오스 및 헤미셀룰로오스와 같은 고분 자 화합물들을 함유하고 있어 제과 및 제빵 등의 고체 식품 
에 국한되어 이용되고 있다. 이러한 고구마의 이용성 증진 을 위해서는 불용성 식이섬유의 저분자화를 통한 수용성 식이섬유 증가를 통해 음료, 수프 등의 증점제와 식품소재 및 식품첨가물로의 활용에 관한 연구가 필요하다고 사료된 다.

식품 분야에서 많이 활용되고 있는 분무건조는 식품소재 의 산화방지 및 소재 안정화와 액상식품 고형화, 식품 소재 의 방출속도 조절 및 물성 향상 등의 장점을 가지고 있다 $(7,8)$. 이러한 분무건조는 핵물질의 특성과 사용될 목적에 따라 피복물질을 선정하여 사용되고 있으며, 분무건조 입 자는 피복물질 종류 및 조성에 의해 그 특성이 결정된다고 보고되고 있다 $(9,10)$. 분무건조를 위해 사용한 펙틴은 식물 의 중엽층에 존재하는 복합 다당류로 주로 a-D-galacturonic acid가 a-1,4 결합을 통해 연결되어 있으며, 이밖에 arabinose, rhamnose, fucose 등의 당류들이 polygalacturonic acid에 가 지처럼 연결된 구조를 가지고 있다(11). 이러한 펙틴은 식품 에서 증점제 및 안정제와 피막제 및 분산제로 주로 사용되 고 있으며, 이밖에도 식이 섬유질인 펙틴은 위에서 분해 흡수되지 않고 장내 미생물에 의해 분해되는 특성 등 다양 한 기능성을 가지고 있어 많은 가공식품에 사용되고 있다 $(12,13)$.

따라서 본 연구에서는 호박고구마로부터 효소 분해에 의해 수용성 식이섬유소를 증가시키고, 소화기관내 생리적 기능을 가지는 펙틴을 피복물질로 사용하여 분무건조 분말 을 제조하였다. 제조된 분무건조 분말은 고구마 제품 개발 시 가공적성, 장내 유용미생물 및 소화율 증진을 조사하여 식품소재 및 식품 첨가물로의 사용 증진을 위한 기초 자료 로 활용하고자 하였다.

\section{재료 및 방법}

\section{실험재료}

본 실험에 사용된 호박고구마는 2016년 해남군에서 재배 된 땅끝누리(안노베니) 품종을 경상북도 경산시 소재의 마 트에서 구입하여 사용하였다. 시료는 흐르는 물에 세척하 고 이물질을 제거한 다음 박피하여 $0.5 \mathrm{~cm}$ 두께로 세절하였 다. 세절된 호박고구마는 열풍 건조기(OF-22, Jeio Tec, Daejeon, Korea)에서 $60^{\circ} \mathrm{C}, 24$ 시간 동안 건조한 다음 분쇄기 (FM-909W, Hanil, Co., Sejong, Korea)로 분쇄한 후 분말로 제조하여 효소 분해용 시료로 사용하였다.

\section{호박고구마 효소 분해}

호박고구마 효소 분해물의 제조는 열풍 건조된 호박고구 마 분말 $10 \mathrm{~g}$ 에 증류수를 고형분 대비 10 배를 첨가한 다음 termamyl(Termamyl $120 \mathrm{~L}, 120 \mathrm{KNU} / \mathrm{g}$ )을 Novozymes A/S (Bagsvaerd, Denmark)에서 구입하여 기질 대비 $3 \%$ 가 되도 록 첨가하여 shaking water bath(BS-31, Jeio Tec, Daejeon,
Korea)에서 $55^{\circ} \mathrm{C}, 100 \mathrm{rpm}$ 및 14 시간 조건으로 반응하여 분해물을 제조하였다.

\section{분무건조 분말 제조}

분무건조 분말 제조는 호박고구마 효소 분해물 1,000 $\mathrm{mL}$ 에 pectin(Sigma-Aldrich Co., St. Louis, MO, USA)을 각 각 $0.1 \%$ (SD-P0.1), $0.5 \%(\mathrm{SD}-\mathrm{P} 0.5), 1.0 \%(\mathrm{SD}-\mathrm{P} 1)$ 및 $2.0 \%$ (SD-P2)를 첨가한 다음 고압균질기(HG-15D, DAIHAN scientific Co., Wonju, Korea)를 이용하여 3,500 rpm에서 20 분간 균질화하였다. 제조된 균질액은 주입 온도 $150^{\circ} \mathrm{C}$, 방출 온도 $100^{\circ} \mathrm{C}$ 로 설정하였고, 분무속도는 $15,000 \mathrm{rpm}$ 에 서 시료공급속도는 $12 \mathrm{~mL} / \mathrm{min}$ 의 조건으로 아토마이저 (Atomizer)가 장착된 분무건조기(KL-8, Seogang Engineering Co., Ltd., Cheonan, Korea)를 이용하여 분말을 제조한 다음, $-70^{\circ} \mathrm{C}$ 이하의 암소에 보관하면서 분석용 시료로 사용하였 다. 대조구로는 피복물질을 첨가하지 않고 동결건조기 (FreeZone-2.5, Labconco Co., Kansas, MO, USA)를 이용하 여 건조한 분말을 사용하였다.

\section{수 율}

수율은 호박고구마 효소 분해물을 분무건조 및 동결건조 한 다음 건물 중량을 구하여 시료 조제에 사용한 원료 건물 량에 대한 백분율로 나타내었다.

\section{수분함량}

수분함량 측정은 분말을 페트리디쉬에 담아 적외선 수분 측정기(MB-45, Moisture analyzer, INC., Ohaus, Parsippany, $\mathrm{NJ}, \mathrm{USA}$ )를 이용하여 $105^{\circ} \mathrm{C}$ 에서 분말의 수분함량이 항량 에 도달할 때까지 건조하여 측정하였다.

\section{식이섬유 함량}

식이섬유 함량은 total dietary fiber assay kit(Megazyme international Ireland Ltd., Wicklow, Ireland)를 이용하여 측 정하였다.

\section{전분함량}

전분함량은 total starch kit(Megazyme international Ireland Ltd.)를 이용하여 제조사의 지침에 따라 측정하였다. 시료 $0.1 \mathrm{~g}$ 에 $80 \%$ 에탄올 $0.2 \mathrm{~mL}$ 를 가한 다음, 열에 안정한 a-amylase $(1,600 \mathrm{U} / \mathrm{mL}) 3 \mathrm{~mL}$ 를 가하여 교반 후 끓는 물에서 6 분간 반응시켰다. 실온에서 $50^{\circ} \mathrm{C}$ 로 냉각 시킨 후 amyloglucosidase $(200 \mathrm{U} / \mathrm{mL}) 0.1 \mathrm{~mL}$ 를 가하여 교반한 다음 $50^{\circ} \mathrm{C}$ water bath에서 30 분간 반응하고 시료를 $100 \mathrm{~mL}$ 로 정용한 후 $3,000 \mathrm{rpm}$ 에서 10 분간 원심분리 하였다. 원심분 리된 상등액 $0.1 \mathrm{~mL}$ 를 취하여 $\mathrm{GOPOD}$ 용액 $3 \mathrm{~mL}$ 를 가하고 $50{ }^{\circ} \mathrm{C}$ 에서 20 분간 발색시킨 다음 분광광도계(Ultraspec 2100pro, Biochrom Ltd., Cambridge, UK)를 이용하여 $510 \mathrm{~nm}$ 
에서 흡광도를 측정하였다. 전분 함량은 아래의 식으로 계 산하였다.

\author{
$\operatorname{Starch}(\%)=\Delta \mathrm{A} \quad \mathrm{FW} \times \mathrm{FV} \times 0.9$ \\ $\triangle \mathrm{A}$ : Absorbance \\ F : $100 \mu \mathrm{g}$ of D-glucose/absorbance for $100 \mu \mathrm{g}$ \\ of D-glucose \\ W : Weight of sample \\ FV : Final volume
}

\section{색도 측정}

색도 측정은 분말을 표준색도가 $\mathrm{L}=94.5, \mathrm{a}=0.18, \mathrm{~b}=0.32$ 로 보정된 색차계(Chromameter CR400, Minolta Co., Osaka, Japan)를 사용하여, 명도를 나타내는 L(lightness), 적색도를 나타내는 a(redness), 황색도를 나타내는 b(yellowness)값을 측정하였으며, 색차 $\Delta \mathrm{E}$ 는 동결건조 분말을 대조구로 하여 아래와 같이 계산하였다.

$$
\Delta \mathrm{E}=\quad \Delta \quad \Delta a^{2}+\Delta b^{2}
$$

\section{입자크기 및 입자표면 구조 측정}

입자크기 측정은 particle size analyzer(LS-13-320, Beckman coulter, Fullerton, CA, USA)를 이용하여 isopropyl alcohol에 분산시켜 측정하였다. 입자표면구조는 각 시료에 gold ion coating한 후 주사형 전자현미경(S-4800, Hitachi highTechnologies Co., Tokyo, Japan)을 이용하였다. 주사형 전자 현미경을 이용한 관찰은 $3.0 \mathrm{kV}$ 에서 500 배 배율로 관찰하 였다.

수분흡수지수(WAI) 및 수분용해지수(WSI) 측정 수분흡수지수(water absorption index, WAI) 및 수분용해 지수(water solubility index, WSI) 측정은 Phillips의 방법(14) 을 변형하여 측정하였다. 동결건조 및 분무건조 분말
$0.5 \mathrm{~g}$ 에 $20 \mathrm{~mL}$ 증류수를 첨가하여 $3,000 \mathrm{rpm}$ 에서 20 분간 원심분리(VS-6000CFN, Vision scientific Co., Bucheon, Korea) 한 후 침전물은 수분흡수지수로 사용하였으며, 상등 액은 미리 무게를 구한 수기에 분리하여 $105^{\circ} \mathrm{C}$ 에서 4 시간 동안 건조시킨 고형분을 수분용해지수로 사용하여 아래와 같이 계산하였다.

$$
\text { WAI }=\frac{\text { Hydrated sample weight-Dry sample weight }}{\text { Dry sample weight }}
$$

$\mathrm{WSI}(\%)=\frac{\text { Dry solid weight recovered by evaporating the supernatant }}{\text { Dry sample weight }} \times 100$

장 상피세포 부착능

장 상피세포(HT-29) 부착능은 Sanae 등(15)의 방법을 일부 수정하여 이용하였으며, Lactobacillus plantarum CGKW3 (KACC92075P) 균주를 MRS broth(Difico Co., Detroit, MI, USA)배지에 24시간 전 배양한 다음 동결건조 및 분무건조 호박고구마 분말 $10 \%$ 를 배양물과 혼합한 후 장 상피세포 부착능을 확인 하였다. 부착능 분석에 사용한 HT-29 (K.30038) 세포는 한국 세포주 은행(KTCC, Seoul, Korea)으 로부터 분양받아 사용하였으며, 세포배양은 RPMI 배지 (Welgene, Daegu, Korea)를 이용하여 각각 10\% fetal bovine serum(Gibco BRL Co., Grand Island, NY, USA), 1\% penicillin-streptomycin(Gibco BRL Co.)을 첨가하여 배양하 였다. 세포는 모두 $37^{\circ} \mathrm{C}, 5 \%$ 로 조절된 $\mathrm{CO}_{2}$ incubator (MCO-18AIC, SANYO Co., Sakata, Japan)에서 배양하였다. 배양된 세포주를 $1 \times 10^{5} \mathrm{cell} / \mathrm{well}$ 의 농도로 조정하여 24-well plate에 48시간 배양하였다. 배양 후 새로운 배지에 시료를 $750 \mu \mathrm{L}$ 처리한 다음 4시간 동안 배양하고 PBS 완충용액을 이용하여 6회 세척한 후 MRS agar(Difico Co.)배지를 사용 하여 $37^{\circ} \mathrm{C}$ 에서 24 시간 배양한 후 형성된 colony 수를 배양물 초기 균수와 계측 비교하여 장내 부착능을 산출하였다.

\begin{tabular}{|c|c|c|c|}
\hline Saliva stock solution & Gastric stock solution & Duodenal stock solution & Bile stock solution \\
\hline $\begin{array}{l}500 \mathrm{~mL} \text { Deionized water } \\
58.5 \mathrm{mg} \mathrm{NaCl} \\
74.5 \mathrm{mg} \mathrm{KCl} \\
1.05 \mathrm{~g} \mathrm{NaHCO}_{3} \\
0.2 \mathrm{~g} \mathrm{Urea}\end{array}$ & $\begin{array}{l}500 \mathrm{~mL} \mathrm{Deionzied} \mathrm{water} .752 \mathrm{~g} \mathrm{NaCl} \\
0.824 \mathrm{~g} \mathrm{KCl} \\
0.266 \mathrm{~g} \mathrm{NaH}_{2} \mathrm{PO}_{4} \\
0.399 \mathrm{~g} \mathrm{CaCl}_{2} 2 \mathrm{H}_{2} \mathrm{O} \\
0.306 \mathrm{~g} \mathrm{NH}_{4} \mathrm{Cl} \\
0.085 \mathrm{~g} \mathrm{urea} \\
6.5 \mathrm{~mL} \text { Concentrated } \mathrm{HCl}\end{array}$ & $\begin{array}{l}500 \mathrm{~mL} \mathrm{Deionzied} \mathrm{water} \\
7.012 \mathrm{~g} \mathrm{NaCl} \\
0.564 \mathrm{~g} \mathrm{KCl} \\
3.388 \mathrm{~g} \mathrm{NaHCO}_{3} \\
80.0 \mathrm{mg} \mathrm{KH}_{2} \mathrm{PO}_{4} \\
50.0 \mathrm{mg} \mathrm{MgCl} \\
0.1 \mathrm{~g} \mathrm{Urea}_{2} \\
0.18 \mathrm{~mL} \mathrm{Concentrated} \mathrm{HCl}\end{array}$ & $\begin{array}{l}500 \mathrm{~mL} \text { Deionzied water } \\
5.259 \mathrm{~g} \mathrm{NaCl} \\
0.376 \mathrm{~g} \mathrm{KCl} \\
5.785 \mathrm{~g} \mathrm{NaHCO}_{3} \\
\\
0.25 \mathrm{~g} \mathrm{Urea} \\
0.15 \mathrm{~mL} \text { Concentrated } \mathrm{HCl}\end{array}$ \\
\hline $\begin{array}{l}\text { adjuncts } \\
0.5 \mathrm{~g} \text { Mucin } \\
1.0 \mathrm{~g} \text { a-Amylase }\end{array}$ & $\begin{array}{l}2.5 \mathrm{~g} \text { Pepsin } \\
3.0 \mathrm{~g} \text { Mucin }\end{array}$ & $\begin{array}{l}9.0 \mathrm{~g} \text { Pancreatin } \\
1.5 \mathrm{~g} \text { Lipase }\end{array}$ & $30 \mathrm{~g}$ Bile salts \\
\hline $\begin{array}{l}\mathrm{PH} \\
6.8 \pm 0.2\end{array}$ & $1.30 \pm 0.02$ & $8.1 \pm 0.2$ & $8.2 \pm 0.2$ \\
\hline
\end{tabular}

Table 1. Compositions of simulated gastrointestinal juices 
Adhesion $(\%)=\left(\mathrm{N}_{1} / \mathrm{N}_{0}\right) \times 100 \%$

$\mathrm{N}_{1}=$ number of adherent lactic acid cells

$\mathrm{N}_{0}=$ number of added lactic acid cells

\section{In vitro 인체 내 소화모델}

In vitro 인체 내 소화모델은 Hur 등(16)의 in vitro human digestion을 일부 수정하여 이용하였으며, 동결건조 및 분무 건조 분말을 single-step model을 이용하여 잔사량 측정을 통해 인체 내 소화모델을 분석하였다. 분석에 사용된 타액 (saliva), 위액(gastric), 장액(duodenal) 및 담즙액(bile) 인공 용액 조성은 Table 1 과 같다. 각 용액 첨가 시 $1 \mathrm{M} \mathrm{HCl}$ (Duksan Pure Chemicals, Seoul, Korea) 및 1 N sodium hydroxide(Duksan Pure Chemicals.)를 사용하여 $\mathrm{pH}$ 를 보정 하였다. 반응은 환류수조(BS-31, Jeio Tech.)에서 $37^{\circ} \mathrm{C}, 50 \times \mathrm{g}$ 으로 진행되었으며, 먼저 삼각플라스크에 시료 $1 \mathrm{~g}$ 및 타액 $6 \mathrm{~mL}$ 를 첨가하여 5 분간 반응한 다음 위액 $12 \mathrm{~mL}$ 를 첨가하 여 2시간 반응하였다. 이 후 장액 $12 \mathrm{~mL}$ 및 담즙액 $6 \mathrm{~mL}$ 를 첨가하여 2 시간 반응을 진행한 다음 $3,000 \mathrm{rpm}$ 에서 20 분간 원심분리 하여 남은 잔사를 건조시킨 고형분의 무게를 측정 하여 소화율로 계산하여 산출하였다.

in vitro digestibility $(\%)=\frac{\text { weight of dried residue }}{\text { weight of initial powder }} \times 100$

\section{통계처리}

실험결과는 3회 반복으로 행하여 평균표준편차로 나타 내었으며 SPSS(19.0, SPSS Inc., Chicago, IL, USA)를 이용 하여 분산분석(ANOVA)을 실시하고, 각 측정 평균값의 유 의성 $(\mathrm{p}<0.05)$ 은 Duncan's multiple range test로 검정하였다.

\section{결과 및 고찰}

\section{식이섬유 함량}

호박고구마 효소 분해물의 불용성 식이섬유, 수용성 식 이섬유 및 총 식이섬유 함량 변화는 Table 2에 나타내었다.
불용성 식이섬유는 무처리 구간에서 $6.04 \%$ 를 나타내어 효 소 분해물에서 $4.17 \%$ 로 감소하였으며, 수용성 식이섬유는 효소 분해물에서 $2.07 \%$ 를 나타내어 무처리 $0.08 \%$ 에 비해 함량이 증가하였다. 총 식이섬유 함량은 효소 분해물에서 $6.24 \%$ 를 나타내어 무처리 $6.12 \%$ 와 유사한 함량을 나타내 었으며, 이는 Shin 등(17)의 전곡립의 압출성형 및 효소 처리에 의한 수용화 연구에서 압출성형 및 효소 처리에 의해 현미와 율무에서 수용성 식이섬유 함량이 증가한다고 보고하였다. 또한, $\operatorname{Han}$ 등(18)의 생식의 전분 가수분해지수 에 열처리가 미치는 영향에 대한 연구에서 열처리에 의해 세포벽내의 펙틴이 B-elimination에 의하여 붕괴되어 용해 성이 증가됨에 의해 총 식이섬유 함량에는 유의적인 차이를 나타내지 않았으나 수용성 식이섬유의 경우 더 높은 값 을 나타낸다고 보고하여 본 연구와 유사한 경향을 나타 내었다.

\section{수율, 수분함량 및 전분함량}

호박고구마 효소 분해물 분무건조 분말의 수율, 수분함 량 및 전분함량은 Table 3과 같다. 호박고구마 효소 분해물 의 수율은 동결건조 분말의 경우 $90.27 \%$ 였고 분무건조 분 말은 72.68-87.12\% 였다. 수분함량은 동결건조 분말의 경우 $2.67 \%$ 를 나타내어 분무건조 분말 $1.68-2.46 \%$ 에 비해 높은 함량을 나타내었다. 이는 분무건조 분말 제조를 위한 분무 건조 공정에서 가열 온도가 증가하면 열전달 효율성의 증가 로 인해 수분함량이 감소한다는 연구보고와 일치하였으며 (19), Kwon 등(20)의 건조방법에 따른 칡 추출물의 품질특 성에서 분무건조 분말에서 동결건조 분말에 비해 낮은 수분 함량을 나타낸다고 보고하여 본 연구결과와 유사한 결과를 나타내었다. 전분함량은 분무건조 분말에서 45.32-46.51\% 의 함량을 나타내어 동결건조 분말 $41.06 \%$ 에 비해 전반적 으로 함량이 증가하는 경향을 나타내었다. 이는 Lee(21)의 가열처리가 잡곡류의 전분가수분해율에 미치는 영향에 대 한 연구에서 원곡에 비해 가열처리하였을 때 전분 함량이 증가하였는데 이는 가열처리에 의해 수용성 성분이 유출됨 에 따라 전분 함량이 높아졌기 때문이라 보고하여 본 연구 에서도 분무건조 공정에 의해 전분함량이 증가한 것으로 사료된다.

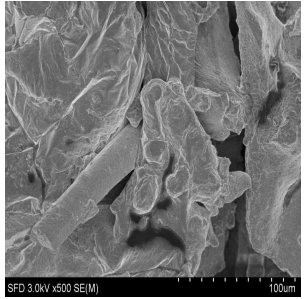

FD

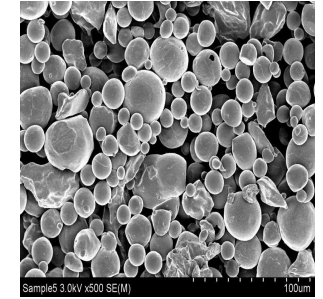

SD-P0.1

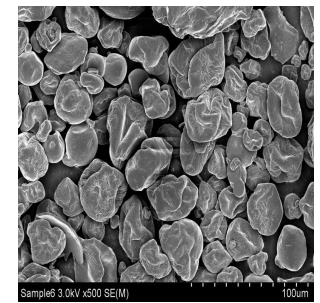

SD-P0.5

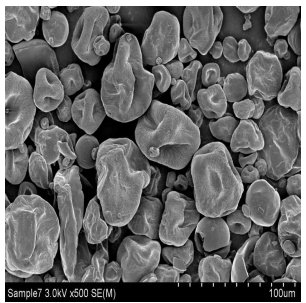

SD-P1

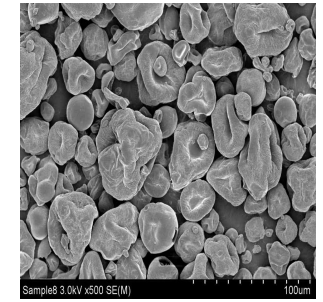

SD-P2

Fig. 1. Scanning electron microscopic photograpghs of spray-dried pumpkin sweet potato hydrolysates (magnification $\times 500$ ).

FD, freeze-dried powder; SD-P0.1, spray-dried powder added pectin 0.1\%; SD-P0.5, spray-dried powder added pectin 0.5\%; SD-P1, spray-dried powder added pectin 1\%; SD-P2, spray-dried powder added pectin $2 \%$. 
Table 2. Dietary fiber composition of the pumpkin sweet potato treated by enzymes

\begin{tabular}{cccc}
\hline \multirow{2}{*}{ Samples } & \multicolumn{3}{c}{ Dietary fiber composition (\%) } \\
\cline { 2 - 4 } & $\begin{array}{c}\text { Insoluble dietary } \\
\text { fiber }\end{array}$ & $\begin{array}{c}\text { Soluble } \\
\text { dietary fiber }\end{array}$ & $\begin{array}{c}\text { Total } \\
\text { dietary fiber }\end{array}$ \\
\hline Control & $6.04 \pm 0.97^{1)}$ & $0.08 \pm 0.02$ & $6.12 \pm 0.81$ \\
Termamyl & $4.17 \pm 0.24$ & $2.07 \pm 0.39$ & $6.24 \pm 0.33$ \\
\hline
\end{tabular}

${ }^{1)}$ All values are expressed as mean $\pm \mathrm{SD}$ of triplicate determinations.

Table 3. Yield, moisture, and total starch of spray-dried pumpkin sweet potato hydrolysates

\begin{tabular}{cccc}
\hline Samples $^{1)}$ & Yield $(\%)$ & $\begin{array}{c}\text { Moisture content } \\
(\%)\end{array}$ & $\begin{array}{c}\text { Total } \\
\text { starch }(\%)\end{array}$ \\
\hline FD & 90.27 & $2.67 \pm 0.10^{\mathrm{a} 2)}$ & $41.06 \pm 0.57^{\mathrm{c}}$ \\
SD-P0.1 & 72.68 & $1.68 \pm 0.04^{\mathrm{d}}$ & $46.39 \pm 0.19^{\mathrm{a}}$ \\
SD-P0.5 & 80.04 & $2.12 \pm 0.07^{\mathrm{c}}$ & $46.51 \pm 0.13^{\mathrm{a}}$ \\
SD-P1 & 87.12 & $2.39 \pm 0.09^{\mathrm{b}}$ & $45.32 \pm 0.45^{\mathrm{b}}$ \\
SD-P2 & 79.04 & $2.46 \pm 0.06^{\mathrm{b}}$ & $45.38 \pm 0.40^{\mathrm{b}}$ \\
\hline
\end{tabular}

${ }^{1)} \mathrm{FD}$, freeze-dried powder; SD-P0.1, spray-dried powder added pectin 0.1\%; SD-P0.5, spray-dried powder added pectin $0.5 \%$; SD-P1, spray-dried powder added pectin $1 \%$; SD-P2, spray-dried powder added pectin $2 \%$.

${ }^{2)}$ Means \pm SD ( $=3$ ) within each column (a-d) followed by the same letter are not significantly different $(\mathrm{p}<0.05)$.

\section{색도, 입자크기 및 입자표면구조}

호박고구마 효소 분해물 분무건조 분말의 색도, 입자크 기 및 입자표면구조는 Table 4에 나타내었다. 분말의 외관 상 품질을 결정하는 요소 중 하나인 색도의 경우 동결건조 분말의 $\mathrm{L}$ 값, $\mathrm{a}$ 값 및 $\mathrm{b}$ 값이 각각 $79.38,0.43,18.54$ 를 나타내 었으며, 분무건조 분말의 경우 L 값은 76.73-80.37을 나타내 었으며, $\mathrm{a}$ 값 및 $\mathrm{b}$ 값의 경우 0.13-0.53 및 17.43-18.45를

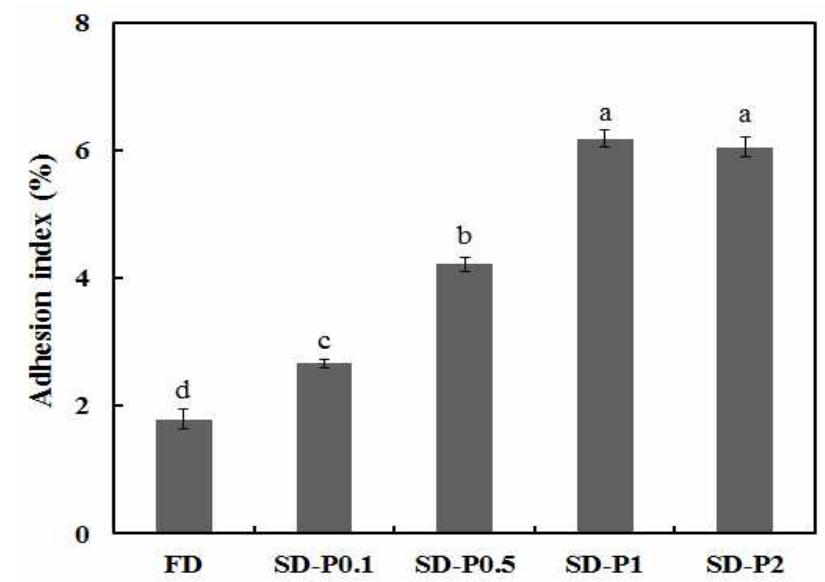

Fig. 2. Adhesion of of spray-dried pumpkin sweet potato hydrolysates to intestinal epithelial HT-29 cells.

FD, freeze-dried powder; SD-P0.1, spray-dried powder added pectin 0.1\%; SD-P0.5, spray-dried powder added pectin $0.5 \%$; SD-P1, spray-dried powder added pectin $1 \%$; SD-P2, spray-dried powder added pectin $2 \%$.

The data are expressed as the means \pm SD $(n=3)$.
나타내어 펙틴 첨가량이 증가할수록 $\mathrm{L}$ 값 및 $\mathrm{a}$ 값은 감소하 고 $\mathrm{b}$ 값은 증가하는 경향을 나타내었다. 동결건조 분말을 대조군으로 하여 본 $\Delta \mathrm{E}$ 값은 1.50-2.67을 나타내어 펙틴 $2 \%$ 첨가 구간에서 색도 변화가 유의적으로 높게 나타났다. 이는 Lee 등(22)의 백미 발효물의 미세캡슐 제조 연구에서 부형제 첨가량이 증가할수록 $\mathrm{L}$ 값 및 $\mathrm{a}$ 값은 감소하고 $\mathrm{b}$ 값은 증가하는 경향을 나타내어 본 연구와 유사한 경향을 나타내었다.

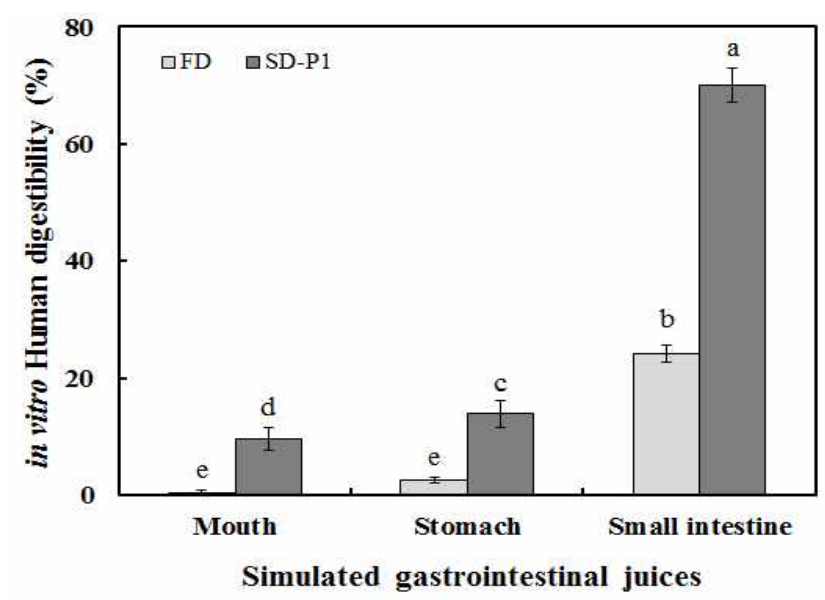

Fig. 3. In vitro Release profiles of spray-dried pumpkin sweet potato hydrolysates. Dissolution behavior in simulated mouth (salivary stock), stomach (gastric stock) and small intestine (duodenal stock and bile stock)

FD, freeze-dried powder; SD-P1, spray-dried powder added pectin $1 \%$. The data are expressed as the means $\pm \mathrm{SD} \quad(\mathrm{n}=3)$.

입자크기는 분무건조 분말에서 37.17-42.32 $\mu \mathrm{m}$ 를 나타내 어 동결건조 분말 $247.79 \mu \mathrm{m}$ 에 비해 유의적으로 낮은 크기 를 나타내었으며, 펙틴 첨가량이 증가할수록 입자크기가 증가하는 경향을 나타내었다. 고구마 분말의 입자크기는 분말 페이스트의 밀도 및 점도에 큰 영향을 주고 고구마 분말을 함유한 식품 시스템의 텍스쳐 품질에 큰 영향을 미친다고 보고하여(23), 분무건조 공정을 통해 유동성이 뛰어난 분말 제조가 가능할 것으로 사료된다. 입자표면구 조는 동결건조 분말의 경우 구형을 형성하지 않고 엉키는 구조를 나타내었으며, 분무건조 분말은 전반적으로 구형의 형태를 나타내고 펙틴 첨가량이 증가할수록 굴곡이 많고 움푹 들어가는 형태를 나타내었다. 이는 Lee와 Hong(24)의 클로렐라 추출물의 분무건조 분말 제조 연구에서 분무건조 분말은 굴곡이 있는 구형을 형성하였으며, 이는 건조 과정 중 입자들이 수축함에 따른 현상이라 보고 하였다.

\section{수분흡수지수 및 수분용해지수}

호박고구마 분무건조 분말의 수분흡수지수 및 수분용해 지수는 Table 5에 나타내었다. 수분흡수지수는 분무건조분 말에서 1.74-1.91을 나타내어 동결건조 분말 2.15에 비해 
Table 4. Hunter's color values, and particle size of spray-dried pumpkin sweet potato hydrolysates

\begin{tabular}{|c|c|c|c|c|c|}
\hline \multirow{2}{*}{ Samples ${ }^{1)}$} & \multicolumn{4}{|c|}{ Hunter's color value } & \multirow{2}{*}{$\begin{array}{c}\text { Particle size } \\
\quad(\mu \mathrm{m})\end{array}$} \\
\hline & $\mathrm{L}$ & a & $\mathrm{b}$ & $\Delta \mathrm{E}$ & \\
\hline FD & $79.38 \pm 0.34^{\mathrm{b} 2)}$ & $0.43 \pm 0.02^{b}$ & $18.54 \pm 0.07^{\mathrm{a}}$ & - & $247.79 \pm 9.24^{\mathrm{a}}$ \\
\hline SD-P0.1 & $80.37 \pm 0.21^{a}$ & $0.53 \pm 0.02^{\mathrm{a}}$ & $17.43 \pm 0.10^{b}$ & $1.50 \pm 0.29^{b}$ & $37.17 \pm 0.08^{\mathrm{d}}$ \\
\hline SD-P0.5 & $79.73 \pm 0.17^{\mathrm{ab}}$ & $0.50 \pm 0.02^{\mathrm{a}}$ & $17.51 \pm 0.10^{b}$ & $1.15 \pm 0.31^{\mathrm{b}}$ & $37.31 \pm 0.21^{\mathrm{d}}$ \\
\hline SD-P1 & $78.16 \pm 0.24^{\mathrm{c}}$ & $0.29 \pm 0.02^{c}$ & $17.54 \pm 0.03^{b}$ & $1.59 \pm 0.08^{b}$ & $41.32 \pm 0.08^{c}$ \\
\hline SD-P2 & $76.73 \pm 0.65^{\mathrm{d}}$ & $0.13 \pm 0.03^{\mathrm{d}}$ & $18.45 \pm 0.11^{\mathrm{a}}$ & $2.67 \pm 0.66^{\mathrm{a}}$ & $42.32 \pm 0.15^{\mathrm{b}}$ \\
\hline
\end{tabular}

${ }^{12} \mathrm{FD}$, freeze-dried powder; SD-P0.1, spray-dried powder added pectin 0.1\%; SD-P0.5, spray-dried powder added pectin 0.5\%; SD-P1, spray-dried powder added pectin $1 \%$; SD-P2, spray-dried powder added pectin $2 \%$.

${ }^{2)}$ Means \pm SD ( $\mathrm{n}=3$ ) within each column (a-d) followed by the same letter are not significantly different $(\mathrm{p}<0.05)$.

낮은 수분흡수지수를 나타내었으며, 펙틴 첨가량이 증가 할수록 수분흡수지수가 증가하였다. Chae와 $\operatorname{Hong}(25)$ 의 자색고구마 추출물의 분무건조 분말 연구에서 수분흡수지 수는 동결건조가 분무건조 분말에 비해 높게 나타난다고 보고하여 본 연구결과와 유사한 경향을 나타내었다. 수분 용해지수는 미세캡슐 분말에서 $80.75-87.61 \%$ 를 나타내었 으며, 동결건조 분말의 경우 $70.47 \%$ 를 나타내었다. 수분용 해지수의 증가는 고구마 분말의 구조적 붕괴정도와 열처리 과정 중 전분의 분해정도에서 차이를 나타낸다고 보고되고 있으며(26), 이는 비 결정 전분입자에 의한 것으로 내부 치밀도가 낮으면 수분의 결합력이 증가한다고 보고되어 있다(27).

Table 5. Water absorption index (WAI) and water solubility index (WSI) of spray-dried pumpkin sweet potato hydrolysates

\begin{tabular}{ccc}
\hline Samples $^{1)}$ & WAI & WSI (\%) \\
\hline FD & $2.15 \pm 0.05^{\mathrm{a} 2)}$ & $70.47 \pm 1.74^{\mathrm{c}}$ \\
SD-P0.1 & $1.74 \pm 0.03^{\mathrm{c}}$ & $81.80 \pm 0.44^{\mathrm{a}}$ \\
SD-P0.5 & $1.77 \pm 0.04^{\mathrm{c}}$ & $80.75 \pm 0.60^{\mathrm{a}}$ \\
SD-P1 & $1.76 \pm 0.05^{\mathrm{c}}$ & $87.61 \pm 0.40^{\mathrm{b}}$ \\
SD-P2 & $1.91 \pm 0.03^{\mathrm{b}}$ & $86.14 \pm 2.91^{\mathrm{b}}$ \\
\hline
\end{tabular}

${ }^{1)} \mathrm{FD}$, freeze-dried powder; SD-P0.1, spray-dried powder added pectin 0.1\%; SD-P0.5, spray-dried powder added pectin $0.5 \%$; SD-P1, spray-dried powder added pectin $1 \%$; SD-P2, spray-dried powder added pectin $2 \%$.

${ }^{2)}$ Means \pm SD (n=3) within each column (a-c) followed by the same letter are not significantly different $(\mathrm{p}<0.05)$.

\section{장 상피세포 부착능}

장 상피세포(HT-29 cell)에 대한 유산균 부착능은 호박고 구마 효소 분해물의 수용성 식이섬유 증가 및 부형제(펙틴) 첨가를 통해 제조한 분무건조 분말을 식품가공용 소재로 활용하고자 장내 유용미생물 증진에 미치는 영향에 대해 조사하였다. 분무건조 분말의 HT-29 세포에 대한 부착능은 초기 유산균 수 대비 2.66-6.18\%를 나타내어 동결건조 분말 $1.79 \%$ 에 비해 높은 부착능을 나타내었다. 이는 $\operatorname{Kim}(28)$ 등 의 Bacillus subtilis로 발효된 곡물의 변비개선효과 연구에
서 발효 곡물에 펙틴 및 알긴산을 첨가한 다음 제조한 미세 캡슐 분말에서 3.17-6.06\%의 장내 부착능을 나타내어 동결 건조물 $0.07 \%$ 에 비해 부착능을 증가시켰다고 보고하여 본 연구결과와 유사하였다. 이러한 장 상피세포 부착능 증가 는 호박고구마 미세캡슐 분말의 수용성 식이섬유 증가에 의한 위장관 내 유용 미생물의 증식을 촉진하는 prebiotics 효과와, 다양한 환경조건과 생리조건에 의해 영향을 받는 온도, 가스 조성, 산도, 삼투작용과 이온작용, 표면장력과 액체 흐름, 세균과의 상호작용과 경쟁 및 장내운동 등에 관여하여 장내 유용미생물 증진에 영향을 미칠 수 있다고 보고되어 있다(29,30).

\section{In vitro 인체 내 소화모델}

호박고구마 분무건조 분말의 물리화학적 특성 및 장 상 피세포 부착능이 우수하게 나타난 펙틴 $1 \%$ 첨가 구간과 동결건조 분말의 인체 내 소화율에 대한 결과를 Fig. 3 에 나타내었다. 분무건조 분말의 경우 타액에서 $9.71 \%$, 위 및 장액에서 각각 $13.94 \%$ 및 $70.09 \%$ 의 소화율을 나타내었으 며, 동결건조 분말의 경우 타액에서 $0.37 \%$, 위 및 소장에서 각각 $2.55 \%$ 및 $24.23 \%$ 의 소화율을 나타내어 분무건조 분말 에서 높은 소화율을 나타내었고 장액에서 유의적으로 높은 소화율을 나타내었다. 이는 Baek 등(31)의 국내 육종 고구 마 전분의 이화학 호화 및 소화 특성 연구에서 소화율은 입자의 평균 크기가 미세하고 slowely digestible starch 및 resistant starch 함량이 상관관계를 가진다고 보고하여 입자 크기가 소화율에 영향을 미치는 중요한 요인이라 보고하였 으며, Park 등(32)의 분무건조공정을 이용한 파인애플 착즙 액 미세캡슐 분말의 in vitro 소화 연구에서 입자크기가 작을 수록 내부 물질을 포접하는데 유리하고 인체 내 소화모델에 서의 안정성 향상에 기여한다고 보고하여 호박고구마 미세 캡슐 분말 제조를 통해 인체 내 유용물질의 증가와 소화 개선을 통한 장내 환경 개선이 가능할 것으로 사료된다. 


\section{요 약}

본 연구에서는 호박고구마의 산업적 이용 증대 및 식품 가공용 소재 개발을 목적으로 분무건조공정을 이용하여 호박고구마 효소 분해물을 분무건조한 다음 물리화학적 특성 및 소화특성을 조사하였다. 호박고구마 효소 분해물 의 불용성 식이섬유, 수용성 식이섬유 및 총 식이섬유 함량 은 $4.17 \%, 2.07 \%$ 및 $6.24 \%$ 이었다. 호박고구마 효소 분해물 의 분무건조분말 제조는 펙틴을 피복물질로 사용하여 분무 건조하였으며, 수분함량 및 전분함량은 1.68-2.46 및 45.32-46.51\%였다. 색도는 분무건조 분말에서 $\mathrm{L}$ 값 및 $\mathrm{a}$ 값은 감소하고 $\mathrm{b}$ 값은 증가하는 경향을 나타내었다. 입자크 기는 분무건조 분말이 37.17-42.32 $\mu \mathrm{m}$ 을 나타내어 동결건 조 분말 $247.79 \mu \mathrm{m}$ 에 비하여 유의적으로 작은 크기를 나타 내었으며, 입자모양은 전반적으로 구형의 형태에 펙틴 첨 가량이 증가할수록 굴곡이 증가하였다. 수분흡수지수는 분 무건조 분말에서 1.74-1.91로 동결건조 분말 2.15에 비해 낮은 수분흡수지수를 나타내었으며, 수분용해지수는 분무 건조 분말에서 $80.75-87.61 \%$ 로 동결건조 분말(70.47\%)보 다 높게 나타났다.

장 상피세포 부착능은 분무건조 분말에서 2.66-6.18\%를 나타내어 동결건조 분말 $1.79 \%$ 에 비해 높은 부착능을 나타 내 장 내 유용 미생물의 증식을 촉진함을 확인하였다. 분무 건조 분말의 인체 내 소화 모델에서, 펙틴 $1 \%$ 첨가 분말은 최종적으로 장액에서 $70.09 \%$ 의 소화율을 나타내어 동결건 조 분말 $24.23 \%$ 에 비해 인체내에서의 높은 소화율이 기대 되었다. 따라서 분무건조 분말 제조시 식품산업 활용 측면 에서 가공적성이 향상되고 in vitro 인체 내 소화모델에서 소화가 개선된 식품가공용 소재 개발에 있어 산업적으로 적용 가능할 것으로 사료된다.

\section{감사의 글}

본 연구는 중소기업청에서 지원하는 2016년도 산학연협 력 기술개발사업(No.C0398270)의 연구수행으로 인한 결과 물임을 밝힙니다.

\section{References}

1. Reddy NN, Sistrunk WA (1980) Effect of cultivar, size, storage, and cooking method on carbohydrates and some nutrients of sweet potatoes. J Food Sci, 45, 682-684

2. Woolfe JA (1992) Sweet potato : untapped food resource. Cambridge University Press, Cambridge, UK, p 1-39

3. Park JW (2009) A study of preference survey on a sweet potato. MS Thesis, Mokpo National University, Korea, p1 4. Lee JS, Ahn YS, Kim HS, Chung MN, Jeong BC (2006) Making techniques of hight quality powder in sweet potato. Korean J Crop Sci, 51, 198-203

5. Kim SY, Ryu CH (1995) Studies on the nutritional components of purple sweet potato (Ipomoea batatas). Korean J Food Sci Technol, 27, 819-825

6. Park SY, Yoon KY (2015) Production of Enzymatic Hydrolysate Including Water-soluble Fiber from Hemicellulose Fraction of Chinese Cabbage Waste. Korean J Food Sci Technol, 47, 6-12

7. Graves RE (1972) Uses for microencapsulation in food additives. Cereal Sci, 17, 107

8. Reineccius GA (1995) Controlled release techniques in the food industry. In : Encapsulation and controlled release of food ingredients. Risch SJ, Reineccius GA (Editor), American Chemical Society, Washington DC, USA, $p$ 8-25

9. Shahidi F, Han XQ (1993) Encapsulation of food ingredients. Crit Rev Food Sci Nutr, 33, 501-547

10. Hogan SA, McNamee BF, O'Riordan ED, O'Sullivan $M$ (2001) Emulsification and microencapsulation properties of sodium caseinate/carbohydrate blends. Int Dairy J, 11, 137-144

11. Joslyn MA (1970) Methods in food analysis : physical, chemical, and instrumental methods of analysis. Academic Press, New York, USA, p 143

12. Hwang JK, Choi MJ, Kim CT (1997) Emulsion properties of casein-alginate mixtures. J Korean Soc Food Sci Nutr, 26, 1102-1108

13. Choi CS, Park SM, Song WH, Lee CM, Lee KY, Kim DW, Kim JC (2003) Release properties of BSA from pectin beads for colonic drug delivery. Korean $\mathrm{J}$ Biotechnol bioeng, 18, 161-164

14. Phillips RD, Chinnan MS, Branch AL, Miller J, Mcwatters KH (1998) Effects of pre-treatment on functional and nutritional properties of cowpea meal. J Food Sci, 53, 805-809

15. Sanae K, Nattakan D, Nattha K, Teerapol S, Malyn C, Sukanya S (2013) In vitro probiotic properties of Lactobacillus fermentum SK5 isolated from vagina of a healthy woman. Anaerobe, 22, 6-13

16. Hur SJ, Lee SK, Kim YC, Choi IW (2012) Development of in vitro human digestion models for health functional food research. Food Sci Ind, 45, 40-49

17. Shin HH, Lee SH, Park BS, Rhim TS, Hwang JK (2003) Solubilization of whole grains by extrusion and enzyme 
treatment. Korean J Food Sci Technol, 35, 849-855

18. Han SH, Han SY, Rhee C (2008) Effect of heat treatment on in vitro hydrolysis index of commercial Saengshik Korean J Food Nutr, 21, 470-476

19. Kang YC, Choi KK, Kim KH, Kim HK (2002) Microencapsulation of aster scaber and aster glehni by spray drying. Korean J Food Preserv, 9, 212-220

20. Kwon YR, Nam S, Jeong DS, Kwon RE, Youn KS (2016) Quality characteristics of Pueraria thunbergiana extracts depending on drying methods. Korean J Food Preserv, 23, 654-659

21. Lee YT (2006) Effect of heat treatments on in vitro starch hydrolysis of selected grains. J Korean Soc Food Sci Nutr, 35, 1102-1105

22. Lee DH, Park HM, Hong JH (2015) Physicochemical properties and microencapsulation process of rice fermented with Bacillus subtilis CBD2. Korean J Food Preserv, 22, 225-231

23. Huang AS, Tanudjaja L, Lum D (1999) Content of alpha-, beta-carotene, and dietary fiber in 18 sweetpotato varieties grown in Hawaii. J Food Compost Anal, 12, 147-151

24. Lee DH, Hong JH (2015) Antioxidant activities and physicochemical properties of extract and spray-dried powder from chlorella. Korean J Food Preserv, 22, 591-597

25. Chae HY, Hong JH (2016) Quality characteristics of spray-dried powder from purple sweet potato extract. J Chitin Chitosan, 21, 271-277
26. Yadav AR, Guha M, Tharanathan RN, Ramteke RS (2006) Changes in characteristics of sweet potato flour prepared by different drying techniques. LWT-Food Sci Technol, 39, 20-26

27. Beleia A, Varriano-Marston E, Hoseney RC (1980) Characterization of starch from pearl millets. Cereal Chem, 57, 300-303

28. Kim BJ, Jung HK, Jeong YS, Yang SJ, Hong JH (2016) Effect of microencapsulated Bacillus subtilis strain $\mathrm{CBD}_{2}$-fermented grain on loperamide-induced constipation in mice. Appl Biol Chem, 59, 451-462

29. Walker AW, Ince J, Duncan SH, Webster LM, Holtrop G, Ze X, Brown D, Stares MD, Scott P, Bergerat A, Louis P, McIntosh F, Johnstone AM, Lobley GE, Parkhill J, Flint HJ (2011) Dominant and diet-responsive groups of bacteria within the human colonic microbiota. ISME J, 5, 220-230

30. Woods MN, Gorbach SL (2001) Influences of fibre on the ecology of the intestinal flora. Handbook of dietary fiber in human nutrition. end ed, CRC Press, Washing DC, USA, p 361-363

31. Baek HR, Kim HR, Kim KM, Kim JS, Han GJ, Moon TW (2014) Characterization of Korean Sweet Potato Starches: Physicochemical, Pasting, and Digestion Properties. Korean J Food Sci Technol, 46, 135-142

32. Park HM, Chae HY, Hong JH (2015) Physicochemical properties and protease activities of microencapsulated pineapple juice powders by spray drying process. Korean J Food Preserv, 22, 84-90 